José Martí 
JOE R. AND TERESA LOZANO LONG SERIES IN

LATIN AMERICAN AND LATINO ART AND CULTURE 


\section{José Martí}

A REVOLUTIONARY LIFE

By Alfred J. López 
Copyright (C) 2014 by Alfred J. López

All rights reserved

Printed in the United States of America

First edition, 2014

Requests for permission to reproduce material from this work should be sent to:

Permissions

University of Texas Press

P.O. Box 7819

Austin, TX 78713-7819

http://utpress.utexas.edu/index.php/rp-form

(a) The paper used in this book meets the minimum requirements of ANSI/NISO Z39.48-1992 (R1997) (Permanence of Paper).

LIBRARY OF CONGRESS CATALOGING-IN-PUBLICATION DATA

López, Alfred J., 1962-

José Martí: a revolutionary life / by Alfred J. López. - First edition.

pages $\quad \mathrm{cm}$. - (Joe R. and Teresa Lozano Long series in Latin

American and Latino art and culture)

Includes bibliographical references and index.

ISBN 978-0-292-73906-2 (cloth : alk. paper)

1. Martí, José, 1853-1895. 2. Revolutionaries-Cuba-Biography.

3. Statesmen-Cuba-Biography. 4. Cuba-History-1878-1895. I. Title. F1783.M38L5769 2014

$972.91^{\prime} 05092-\mathrm{dc} 23$

[B]

2014012771

doi: $10.7560 / 739062$ 
For Susan, wife, best friend, and honorary Cuban 
THIS PAGE INTENTIONALLY LEFT BLANK 